\title{
Genetic Relationship amongSome Wheat Genotypes Using Ten ISSR Markers
}

\author{
Melathkadem FarhoodAL- Ghufaili; Attyaf Jameel Thamir Al-Tamimi \\ Faculty of Science, University of Kufa
}

\begin{abstract}
Ten of ISSRs (inter- Simple Sequence Repeats) markers were used for revealing genetic relationship, genetic diversity and DNA fingerprint of ten bread wheat (Triticumaestivum L.) genotypes. Primers varied among them in giving unique DNA fingerprint hence primers HB12, UBC81landUBC852 gave unique fingerprint for all ten studied wheat genotypes, others varied between 2-6 fingerprint genotypes while primer 17899A gave no unique fingerprint. High genetic distance was 0.661 while low genetic distance was 0.131.Cluster analysis (Phylogenetic tree) grouped studied genotypes in to two main groups, the first small one included only one genotype while the other large main group included the rest genotypes which further divided in to two sub groups. ISSRs represent good marker for revealing genetic diversity and genotypes fingerprinting. The results could help plant breeder in breeding programs.
\end{abstract}

Key words:Bread heat, ISSR markers, Geneticdiversity, Dendrogram,cluster analysis

\section{Introduction}

Wheat is an annual plant belongs to the grass family Poaceae (Graminae) (Pathak and Shrivastav, 2015), which contributes more calories and proteins to the world diet than any other cereal crops (Shewry, 2007).The first step in crop improvement including wheat is complete molecular characterization of germplasm. Our Knowledge about genetic relationships and genetic diversity among breeding lines could help in strategies used for crop improvement (Abbas et al., 2008). Genetic diversity of plants determines their potential for improvement and their use for breeding, which eventually enhanced food production. (Khodadadiet al., 2011). Characterization of genotypes is accomplished by different markers including; morphological markers (phenotypic markers) which depend on the experience of the breeder to correlate a phenotypic trait with a trait of interest (Wettstein-Knowles, 1992), they are easy to detect and measure, and their relevance to germplasm users and breeders (Lombard et al., 2001), but there is complex genetic control of many morphological traits and they can be influenced by environmental conditions (Lombard et al., 2001).Biochemical markers are reliable in genetic studies and breeding of plant species because their stability in expression independently of surrounding environmental factors, ability to assess co-dominance, high reproducibility, ease of use and low costs (Kumar et al., 2009), but enzyme locus describes small and not randomly part of genome and very affected by methods of extraction, plants growth stages and plant tissues (Mondiniet al., 2009), in addition they are relatively low in their distribution and their low level of polymorphism (Krieger and Ross, 2002).

DNA markers defined as a sequence of DNA or a gene, which is situated on a chromosome (Collard et al., 2005andSchulmann, 2007) by which it could detect differences between individuals by showing polymorphism (Collard et al., 2005). DNA markers are consider very efficient in selection of plant material, not affected by the environment, their segregation as single genes. DNA is extracted easily from plant materials (Ovesnaetal., 2002).DNA markers usefully used in identification of genetic materiales, selection of parents, detection of the progeny, characterization of the varieties for protection of both, consumers and breeders rights. (Ovesna, etal., 2002). Among DNA markers, inter simple sequence repeats (ISSR) markers need small quantities of DNA and not require radioactive labels, it is simple and faste.ISSRwas a powerful, reproducible, simple, rapid, and inexpensive tool to estimate genetic variation and identifying differences among closely related cultivars in many species. (Solimanaet al.,2014), because breeders use common breeding material of other breeding institutes or share common parents/lines, this lead to similar parents in breeding programs which result in lack of genetic variation. (Iqbalet al., 1997, Rehmanet al., 2002).It is very important to study germplasm genetic composition of modern-day cultivars and compare them with their related species and ancestors. This will provides information's about their phylogenetic relationship and produce a chance to find a new useful genes, because accessions possess distinct DNA profiles is always contain a large number of novel alleles (Messmeret al., 1992), so this study was conducted to evaluate wheat germplasm variation and fingerprinting studied genotypes. 


\section{Materials and methods}

DNA extraction and PCR amplification:ten of wheat genotypes with diverse characterization and pedigree were used for DNA extraction (table.1). Fresh young leaves at age of two weeks were used for DNA extraction using The Genomic DNA Mini Kit (Geneaid Biotech. Ltd; Taiwan Company). PCR reaction mixture was prepared as follows: $6 \mu 1$ template DNA and $3 \mu \mathrm{l}$ of primer (10 pmole/ $\mu \mathrm{l})$, were added to each PCR Pre Mix tube and sterilized deionized distilled water was added to to the final volume of $20 \mu$ l.Ten ISSR markers were examined for fingerprinting genotypes as listed in table .2. Amplification was performed in thermocycler programmed according to annealing temperatures produced in table .3. The amplified DNA product were separated by electrophoresis on $2 \%$ agarose gels stained with ethidium bromide $(5 \mu 1$ of ethidium bromide solution ) electrophoresis runs for $3 \mathrm{hr}$ at $70 \mathrm{~V}$ and then visualized under $\mathrm{UV}$ light and photographs.Presence of a product was identified as (1) and absence was identified as (0). Data were scored for all genotypes, their amplification product and primers. The data then entered into NTSYS-PC (Numerical Taxonomy and multivariate Analysis System), Version 1.8 (Applied Biostatistics) program [19]. A Dendrogram was constructed based on genetic distance: genetic distance (GD) =1- genetic similarity (GS) using the Unweighted Pair-Group Method with Arithmetical Average (UPGMA).

Table (1) Genotypes characterization.Table (2) Names and sequences of ISSRs primers .

\begin{tabular}{||c||l||l||}
\hline \hline No. & Name & Pedigree \\
\hline \hline 1 & Furat & $\begin{array}{l}\text { Foreign genetic structures 5H in F2 } \\
\text { (second generation) }\end{array}$ \\
\hline \hline 2 & Baghdad & Australian strain $\times$ Aras \\
\hline 3 & Hashimia & $\begin{array}{l}\text { A-901Y-902D-OY/LD*6/FB6628- } \\
\text { F30069BR12*3/3BR14) }\end{array}$ \\
\hline \hline 4 & Buhuth22 & $\begin{array}{l}\text { The Ministry of Science and } \\
\text { Technology/Iraq }\end{array}$ \\
\hline 5 & Latifia & Australian strain×MexicanArasvareity \\
\hline \hline 6 & Dijla & $\begin{array}{l}\text { American genetic structures 655in } \\
\text { their F2 generation }\end{array}$ \\
\hline \hline 7 & Abaa 99 & (Ures/Bow"s"/3/Jup/Biy"s"/urse) \\
\hline \hline 8 & Rasheed & $\begin{array}{l}\text { Radiation of pure strain of maxi pack } \\
\text { with Gama ray (10Krad) }\end{array}$ \\
\hline \hline 10 & Iraq & $\begin{array}{l}\text { The Ministry of Science and } \\
\text { Technology/Iraq }\end{array}$ \\
\hline \hline
\end{tabular}

\begin{tabular}{|c|c|}
\hline $\begin{array}{l}\text { ISSRs } \\
\text { Primers }\end{array}$ & Sequence $5^{\prime} \longrightarrow \mathcal{3}^{\prime}$ \\
\hline $844 \mathrm{~A}$ & 5' CTC TCT CTC TCT CTC TGC 3' \\
\hline $844 B$ & 5' CTC TCT CTC TCT CTA 3' \\
\hline 17889A & 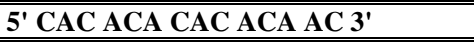 \\
\hline HB12 & 5' CAG CAGCAG GC 3' \\
\hline UBC814 & $\begin{array}{l}\text { 5'CTCTCTCTCTCTCTCTCTA3' } \\
\end{array}$ \\
\hline UBC-811 & $\begin{array}{l}\text { 5'GAGAGAGAGAGAGAGAAC3' } \\
\end{array}$ \\
\hline UBC-881 & $\begin{array}{l}\text { 5'GGGTGGGGTGGGGTG3' } \\
\end{array}$ \\
\hline UBC 852 & 5' GATAGATAGACAGACA 3' \\
\hline HBS10 & 5' GAG AGA GAG AGA CC 3' \\
\hline 17899A & ' 5' CAC ACA CAC ACA AG 3' \\
\hline
\end{tabular}

Table (3): ISSRs primers with their PCR amplification programs.

\begin{tabular}{|c|c|c|c|}
\hline ISSRs annealing temperature & Step & Temperature & Time \\
\hline \multirow{2}{*}{$\begin{array}{l}\text { UBC-852 }\left(49 \mathrm{C}^{\circ}\right) \\
\text { UBC881 }\left(52 \mathrm{C}^{\circ}\right)\end{array}$} & Initial denaturation & $94 \mathrm{C}^{\circ}$ & $5 \mathrm{~min}$ \\
\hline & \multicolumn{3}{|c|}{$\begin{array}{ll}\text { No. of Cycles }=30 \text { Cycles } \\
\end{array}$} \\
\hline \multirow{4}{*}{ 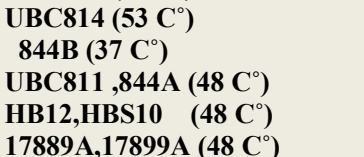 } & Denaturation & $94 \mathrm{C}^{\circ}$ & $1 \overline{1 \min }$ \\
\hline & Annealing & Variable & 1min \\
\hline & Extension & $72 \mathrm{C}^{\circ}$ & 2 2min \\
\hline & Final extension & $72 \mathrm{CC}^{\circ}$ & $7 \mathrm{7min}$ \\
\hline
\end{tabular}

\section{Results and Discussion}

Using Bio drop apparatus the concentration of isolated DNA was $73.91 \mu \mathrm{g} / \mathrm{ml}$ with purity 1.9, ISSRsprofile results showed variation among studied genotypes through presence of monomorphic, polymorphic and unique bands. Primers HB12, UBC811 and UBC852 gave unique fingerprint for each genotype while primer 17899A failed to give unique fingerprint, other primers ranged (2-5) in their fingerprinted genotypes.Table 4. results show that these three primers gave the higher value for polymorphism, HB12, UBC811 and UBC852 (64.7, 68.7 and 52.6) respectively. Polymorphism increased with increasing number of polymorphic bands (Hunter and Gaston, 1988 and Graham and McNichol, 1995), and increases chance of producing unique fingerprint. Primer which produces high polymorphic bands can be further used as polymorphic marker which will prove promising in identification and genetic purity testing of crops (Pal and Singh, 2013).Product of PCR amplification fragment shown in figures (1-10).Results in table (5) show that the higher molecular size and lower molecular size was $1717 \mathrm{bp}, 138 \mathrm{bp}$ respectively in primer UBC852. Size of amplified fragments related to primer sequence annealed with DNA template. (Mahparaet al., 2012).Insertions and deletions could change the size of the amplified product (Powell et al., 1996;Fadoulet al.,2013). The higher number of main bands was 19 in 
UBC852 while the lower was six bands in primer 844B.The higher number of amplified bans was 142 bands in primer 17899A while lower number of amplified bans was 45 bands in primer 844B. Variation in number of main and amplified bands are mainly due to primer structure and that some primers recognize a high number of annealing site, which is more useful than primers recognizing lower number of annealing sites. In this case the number of amplified bands will be higher, thus giving a better chance for detecting DNA polymorphisms among individuals (Williams et al., 1990;Tahir, 2014).

Table (4) Wheat genotypes fingerprinting (DNA profile) using ten ISSRs primers and their sequences.

\begin{tabular}{|c||c||c||c||c||}
\hline \hline No. & Primers & Sequence (5'-3') & $\begin{array}{c}\text { Varieties } \\
\text { fingerprinting }\end{array}$ & $\begin{array}{c}\text { No. of varieties } \\
\text { fingerprint }\end{array}$ \\
\hline \hline 1 & 844A & 5' CTC TCT CTC TCT CTC TGC 3' & $5,6,8$ & 3 \\
\hline \hline 2 & 844B & 5' CTC TCT CTC TCT CTA 3' & 1,5 & 2 \\
\hline \hline 3 & 17889A & 5' CAC ACA CAC ACA AC 3' & $1,2,3,5,7,8$ & 6 \\
\hline \hline 4 & 17899A & 5' CAC ACA CAC ACA AG 3' & - & - \\
\hline \hline 5 & HB12 & 5' CAGCAGCAG GC 3' & $1,2,3,4,5,6,7,8,9,10$ & 10 \\
\hline \hline 6 & HBS10 & 5' GAG AGA GAG AGA CC 3' & $3,5,6$ & 3 \\
\hline \hline 7 & UBC811 & 5'GAGAGAGAGAGAGAGAAC3' & $1,2,3,4,5,6,7,8,9,10$ & 10 \\
\hline \hline 8 & UBC814 & 5'CTCTCTCTCTCTCTCTCTA3' & $1,5,8,9,10$ & 5 \\
\hline \hline 9 & UBC852 & 5' GATAGATAGACAGACA 3' & $1,2,3,4,5,6,7,8,9,10$ & 10 \\
\hline \hline 10 & UBC881 & 5'GGGTGGGGTGGGGTG3' & $2,3,8,6$ & 4 \\
\hline
\end{tabular}

Most of chosen primers in this study were di-nucleotide motif primers, primers of dinucleotide repeat markers revealed maximum amplification which found to be more amenable in wheat and especially 3'anchored di-nucleotide motif primers which gave clear amplified products, whereas 5'-anchored dinucleotide primers were excluded because they give either poor or no amplification in wheat genotypes as reported (Pujoret $a l, 1999)$. Monomorphic bands were thirteen in primer 17899A while in primer HB12 were only one band. AlJudy (2004) reported that genome contains constant identical sequences commonly refer to as conserved sequence. Monomorphic bands are type of these sequences, which reveal that genotypes that belong to one species share some genome sequences and differ in others (Russel, et al., 1997; Al-Judy, 2004 and AL-Badeiry, 2013; AL-Tamimi, 2014). The higher polymorphic bands were eleven in HB12 and UBC811 primers whileprimers 844A and 844B gave only two polymorphic bands .High polymorphism observed using primers UBC811, UBC852 and HB12 while primer 17899A gave lowest polymorphism. Studies reported that primers with di-nucleotid GA sequence give low polymorphism(Akkayaet al.,1992; Singh and Jaiswal,2016), this was correct for primer HBS10 while primer UBC811 gave high polymorphism, this may resulted from nucleotide sequence changes by deletion or insertions that may change level of polymorphism by changing primer annealing sites (Powell et al., 1996;Fadoulet al.,2013), others studies confirmed that GA sequence showed stable amplification and rich polymorphism (Liu et al., 2010; Yousefiet al.,2015). Polymorphism level increased by using tri- HB12 and tetra- UBC852 nucleotide sequence (Pujoret al, 1999).Primers sequences which composed of di- nucleotide sequence give low polymorphism while tetra- and penta-nucleotide repeat sequences gave different high level of polymorphism (Nagoaka and Ogihara, 1997; Sofalianetal., 2008).The higher number of unique bands was five in primers HB12 and HBS10 while primer UBC881 gave only one band. Primers 844B, 17899A and UBC814 gave no unique band. the presence of such bands refer to that primer recognized a unique annealing site in genome, this increase chance of producing a unique cultivar fingerprint (Grewalet al.,2007;Vishwanath et al., 2010; Fadoulet al.,2013;AL-Tamimi,2014) .Primer 17899A gave lowest value for efficiency in contrast to primer HB12 which gave higher value. Discriminatory value in both primers HB12 and UBC811 was the highest while primers 844A and 844B gave the lowestvalue. Both efficiency and discriminatory value of primer concerned with its ability to give uniquefingerprint .(Newton and Graham, 1997; Arif et al., 2010 and AL-Badeiry, 2013; AL-Tamimi,2014), this was clearly observed in primers HB12,UBC811 and UBC852 which were high in their both efficiency and discriminatory value and they gave a unique fingerprint.In table (6) the results showed that the highest genetic distance was observed between Furat and Hashimia genotypes while lowest genetic distance was between Abaa99 and Iraq genotypes. Variation in genetic similarity may be attributed to the genealogy of the cultivars, because some of them have a common parent or not, authors emphasized that there is possibility of forming groups could be linked to the sharing of genetic material from one distant common ancestor; it would explain the genetic similarity, the presence of common ancestors might have influenced the similarity among the cultivars in the present study. (Morale et al., 2011).According to dendrogram produced in figure (2) there were two main clusters, the first small cluster included only Furat genotype while the other large cluster included two sub groups; the small one included the genotypes Hashimia, Rasheed and Faris, the other large one included genotypes Baghdad, Buhuth22, Latifia,Dijla,Abaa99andIraq. The evolution leading to adaptation to different agroecological conditions may 
mutate the SSR sequences, which lead to differences in the ISSR amplification pattern result in diverse phyllogenetic relationships Regardless of different geographical locations of the place of release of varieties and different ploidy levels.( Singh and Jaiswal.,2016).

Table ( 5 ) Summarized results of ISSRs amplification product include :fragment size range in bp ; No. of : main , amplified ,monomorphic, polymorphic and unique bands ; polymorphism (\%), efficiency and discriminatory value $(\%)$ of primers.

\begin{tabular}{|c|c|c|c|c|c|c|c|c|c|c|}
\hline No. & Primen & Stas in (Bp) & main & smplined & mone & peity & waiges & $\begin{array}{l}\text { Poby warphium } \\
(4 \%)\end{array}$ & Emeiensy & $\begin{array}{l}\text { Discriminasten } \\
\text { Veles (t6) }\end{array}$ \\
\hline 1 & s44A & 160.529 & e & 74 & $s$ & 2 & 2 & 22.22 & 0.027 & 3.546 \\
\hline 2 & 8448 & $413-1200$ & 6 & is & 4 & 2 & . & 33.33 & 0.0444 & 3.846 \\
\hline 3 & $17889 \mathrm{~A}$ & $143-1482$ & 16 & 118 & 8 & 4 & 4 & 25 & 0.0339 & 7.692 \\
\hline 4 & $17599 \mathrm{~A}$ & 186.1492 & 16 & 142 & 13 & 3 & - & 18.75 & 0.0211 & 5.760 \\
\hline 3 & HB12 & $184-1297$ & 17 & 66 & 1 & 11 & $s$ & 64.705 & 0.1666 & 21.153 \\
\hline 6 & HBsı & 223-1113 & 15 & 102 & 7 & 3 & 5 & 20 & 0.0294 & 5.769 \\
\hline 7 & cacsin & 163.606 & 16 & 53 & 3 & 11 & 2 & 65.75 & 0.132 & 21.153 \\
\hline 8 & Eacait & $152-866$ & 10 & 75 & 6 & 4 & , & 40 & 0.0833 & 7.692 \\
\hline 9 & UBC85: & 138-1717 & 19 & 127 & 6 & 10 & 3 & 52.631 & 0.0787 & 19.230 \\
\hline 10 & vncass & $196-607$ & 11 & 77 & 7 & 3 & $\mathrm{t}$ & 27.27 & $0.03 s 9$ & $\$ .769$ \\
\hline \multicolumn{3}{|c|}{ Yotal no. of bandh } & 135 & 909 & 60 & s3 & 12 & - & - & - \\
\hline \multicolumn{3}{|c|}{ Arerage bands per primer } & 13.5 & 90.9 & 6 & 5.3 & 2.2 & - & - & - \\
\hline \multicolumn{3}{|c|}{ Average per priater 08} & . & " & - & . & . & 37,2656 & 0.06252 & 10.1919 \\
\hline
\end{tabular}

Table (6) The genetic distance .

\begin{tabular}{|c|c|c|c|c|c|c|c|c|c|}
\hline 1 & & & 1 & 6 & 5 & 8 & i & 1 & 8 \\
\hline 1 & 8 & & & & & & & & \\
\hline 2 & Ins & $d$ & & & & & & & \\
\hline 3 & 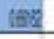 & taxi: & 1 & & & & & & \\
\hline \pm & $\operatorname{tax}$ & (2) & Ex: & 1 & & & & & \\
\hline 5 & (1) & $18 x \mid$ & 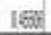 & 1 ixy & 1 & & & & \\
\hline 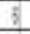 & (6) & 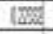 & ICA7] & $1 K^{\prime}$ & $1 \sqrt{10}$ & 1 & & & \\
\hline T & 101 & (1) & 150 & ISEA & 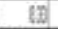 & 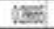 & 1 & & \\
\hline 8 & $62 \%$ & |कास & 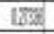 & 156 & 200 & ACS: & 2085 & 1 & \\
\hline 8 & 6 b & 테 & (दाlी & 1908 & 1200 & $\Delta \mathrm{se}$ & 12 & DIS & 1 \\
\hline 1 & $1 \pi \%$ & I I I I & 1) & 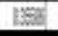 & 145 & 15 & 210. & $1 \mathrm{Is}$ & Mat \\
\hline
\end{tabular}

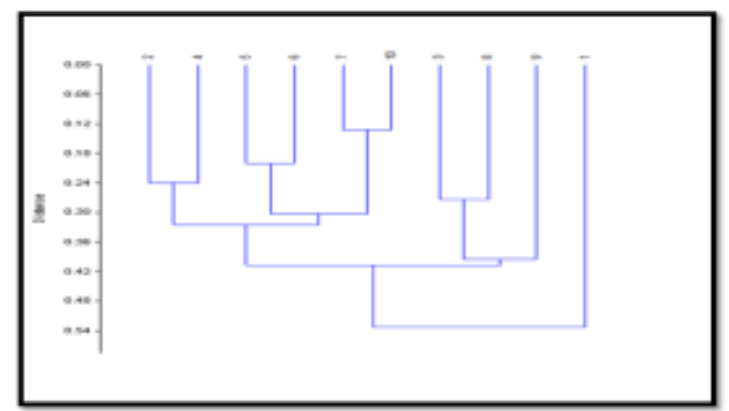

Figure (2) UPGMA dendrogram.

\section{Conclusions:}

Low genetic diversity among studied wheat genotypes revealed by ISSR markers, which indicate the narrow genetic base of wheat crop in Iraq, on the basis of results of this study.
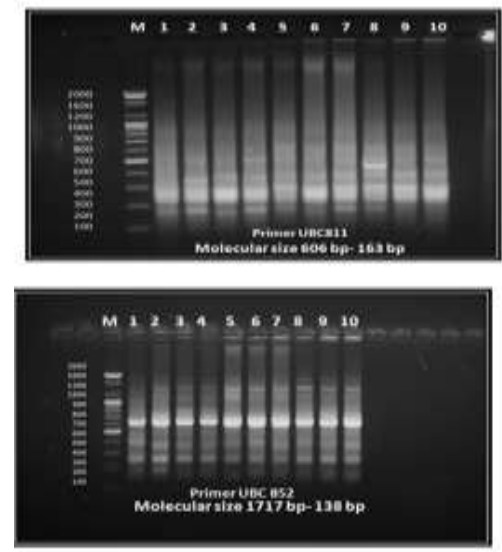

DOI: $10.9790 / 3008-1203063036$
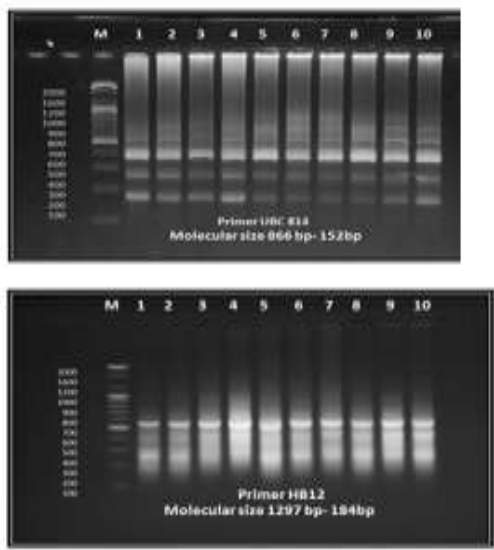

www.iosrjournals.org
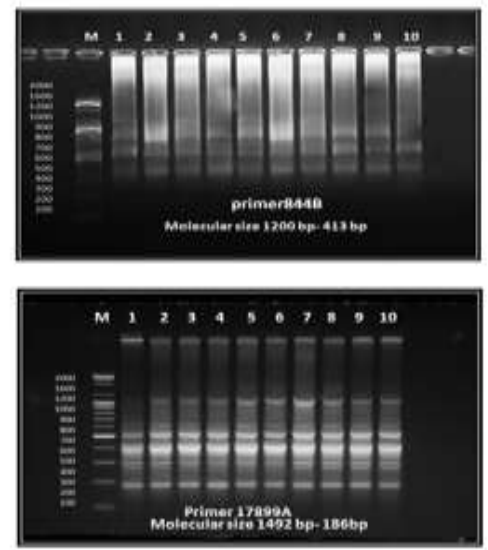

$33 \mid$ Page 

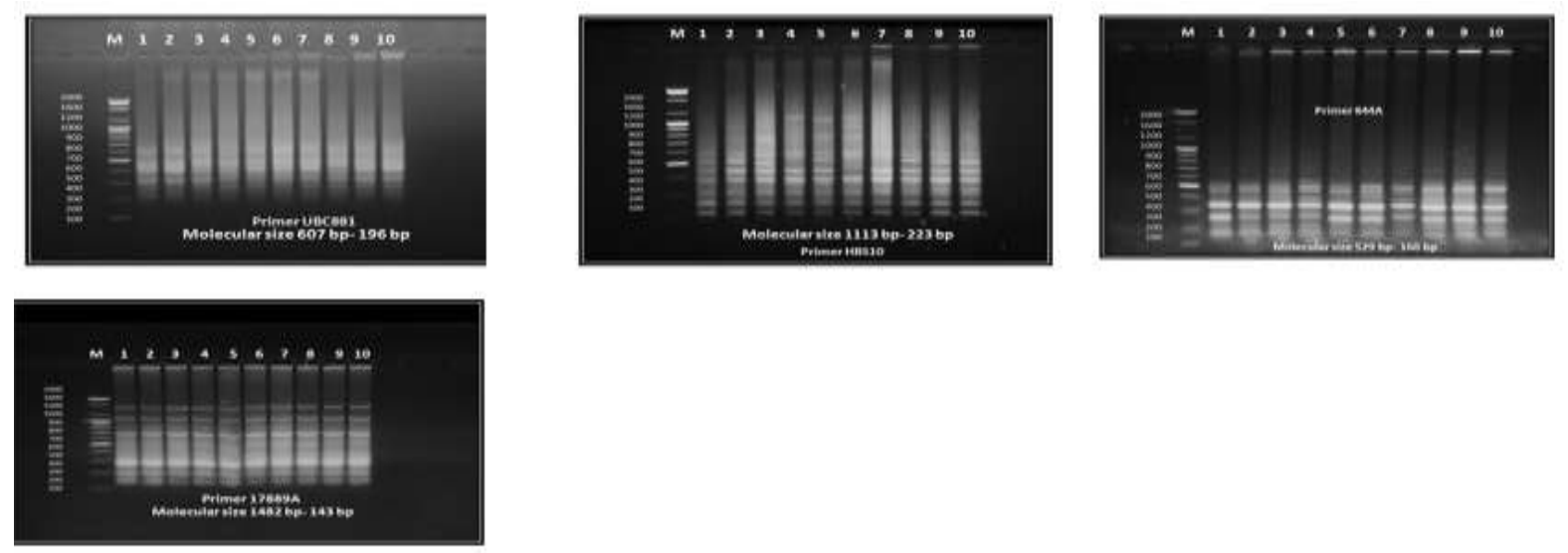

Figures (1-10): The electrophoresis profile obtained by ISSR primers, lane M: DNA ladder and lanes 1-10: Wheat genotypes

\section{References}

[1]. Abbas, S.J.; Shah,S.R.U.; Rasool,G.andIqbal,A.(2008). Analysis of genetic diversity in Pakistani wheat varieties by using randomly amplified polymorphic DNA (RAPD) primers American-Eurasian Journal of Sustainable Agriculture, 2(1): 29-33.

[2]. Abou-Deif, M. H.; Rashed, M. A.; .Sallam, M. A. A.; Mostafa, E. A. H. and Ramadan,W.A.(2013).Characterization of Twenty Wheat Varieties by ISSR Markers. Middle-East Journal of Scientific Research 15 (2): 168-175.

[3]. Akkaya, M.S.; Bhagwat, A.A. and Cregan, P.B. (1992). Length polymorphisms of simple sequence repeat DNA in soybean. Genetics, 132: 1131-9.

[4]. Al-Badeiry , N. A.M.(2013).Molecular and Cytological Studies on Some Zea mays Varieties in Iraq .Phd thesis, University of Kufa ,Faculty of Science ,Department of Biology , Iraq.

[5]. Al-Judy, N.J. (2004).Detecting of DNA Fingerprints and Genetic Relationship Analysis in Local and Improved Rice (Oryza sativa L.) Varieties in Iraq Using RAPD Markers.Ph.D thesis, College of Science, Baghdad University, pp 166.

[6]. AL-Tamimi, A. J.T. (2014). Genetic Diversity of Some Tomato Genotypes Using RAPD and SSR markers in Iraq .PhD thesis .Faculity of science.University of kufa. $p 183$.

[7]. Arif, I. A.; Bakir, M. A.; Khan, H. A.; Al-Farhan, A. H.; Al-Homaidan, A. A.; Bahkali, A. H.; AlSadoon, M. and Shobrak, M. (2010). Application of RAPD for molecular characterization of plant species of medicinal value from an arid environment.Genet. Mol. Res., 9 (4): 2191-2198.

[8]. Collard, B.C.Y.; Jahufer, M.Z.Z and Pang, E.C.K. (2005).An introduction to markers, quantitative trait loci (QTL) mapping and marker-assissted selection for crop improvement: The basic concepts.Euphytica, 142(1-2): 169-196.

[9]. Fadoul, H. E.; El Siddig, M. A.; and El Hussein, A. A. (2013). Assessment of genetic diversity among Sudanese wheat cultivars using RAPD markers. INT J CURR SCI. 6: E 51-57.

[10]. Graham, J. and McNicol, R. J. (1995). An examination of the ability of RAPD markers to determine the relationships within and between Rubus spp. Theo. Appl. Gene., 90: 1128-1132.

[11]. Grewal, A.; Kharb, P.; Malik, R.; Jain, S.and. Jain, R. K. (2007).Assessment of genetic diversity among some Indian wheat cultivars using random amplified polymorphic DNA (RAPD) markers .indian Journal of Biotechnology , 6, pp 18-23.

[12]. Hunter, P. R. and Gaston, M. A. (1988). Numerical index of discriminatory ability of simpson's index of diversity. J. Clin. Mic., 26:2465-2466.

[13]. Iqbal, M.J., N. Aziz.,N.A. Saeed., Y. Zafar and K.A. Malik. 1997. Genetic diversity evaluation of some elite cotton varieties by RAPD analysis. Theor, Appl, Genet. 94: 139-144. 
[14]. Khodadadi, M.; Hhossein,F. and Miransari,M.(2011).Genetic diversity of wheat (Triticumaestivum L.).Genotypes based on cluster and principal componenet analysis for breeding strategies .A.J.C.S.5 (1):17-24.

[15]. Kreiger, M.; Ross, K.G. (2002).Identification of a major gene regulating complex social behavior. Science, 295:328-332.

[16]. Kumar,P.; Gupta,V.K.; Misra,A.K.andPandey,B.K.(2009).Potential of molecular markers in plant biotechnology. Plant Omics Journal.2 (4):141-162.

[17]. Liu, D.; X.He; G.Liu and B.Huang (2010). Genetic diversity and phylogenetic relationship of Tadehagi in southeast China evaluated by intersimple sequence repeat (ISSR). Genet.Resour. Crop Evol. 58: 679-687.

[18]. Lombard, V.; Dubreuil, P.; Dillmann, C. and Baril, C.P. (2001).Genetic distance estimators based on molecular data for plant registration and protection: a review. Acta Horticultura.546:55-63.

[19]. Mahpara, S. Farooq, J. Ali, Z.; Petrescu-Mag, I. V.andHussain, F. (2012).Assessment of genetic distance among wheat genotypes through RAPD markers.Advances in Agriculture \&Botanics International Journal of the Bioflux Society. Volume 4 (1):31-35.

[20]. Messmer, M.M.; Melchinger,A.E.; Boppenmaier,J.; Herrmann,R.G. and Brunklaus-Jung,E. (1992). RFLP analysis of early-maturing Eurpeonmaizgermplsm.Theor.Appl.Genet. 83: 1003-1112.

[21]. Mondini,L.; Noorani,A.andPagnotta ,A.(2009). Assessing Plant Genetic Diversity by Molecular Tools. Diversity.1, 19-35.

[22]. Morale,G.F.;Resende, J. T.V.; Faria, M.V.; Andrade, M. C. ; Resende, L.V.; Delatorre, C. A. and Da Silva, P.R..(2011).Genetic similarity among strawberry cultivars assessed by RAPD and ISSR markers. Sci. Agric., 68(6):665-670.

[23]. Nagoaka, T. and Ogihara, Y. (1997).Applicability of inter- simple sequence repeat polymorphisms in wheat for use as DNA markers in comparison to RFLP and RAPD markers. Theor. Appl. Genet., 94: 597-602.

[24]. Newton, C. R. and Graham, A. (1997).Polymerase Chain Reaction.2nd ed. Bios.Scientific Publishers Ltd., Oxford, U.K.

[25]. Ovesna, J.; Pplakova,K.andLeisova,L.(2002).DNA Analyses and their Applications in Plant Breeding.Czech J. Genet.Plant Breed. 38, 2002 (1): 29-40.

[26]. Pal, D. and Singh, M. (2013).Molecular Profiling and RAPD analysis of Commercial Hybrid Parental Lines in Tomato and Chili. IJIRSET, 2(9): 4288- 4292.

[27]. Pathak and Shrivastav, S. (2015). Biochemical studies on wheat (Triticumaestivum L.). Journal of Pharmacognosy and Photochemistry; 4(3): 171-175.

[28]. Powell, W.; Morgante, M.; Andre C.; Hanafey, M.; Vogel, J.; Tingey, S. and Rafalski, A. (1996).The comparison of RFLP, RAPD, AFLP and SSR (microsatellite) markers for germplasm analysis. Mol Breed 2: 225-238.

[29]. Pujor, S.; Tamhankar, S.A.; Rao, V.S.; Gupta, V.S.; Naik, S. and Ranjekar, P.K. (1999). Arbitrarily primed-PCR based diversity assessment reflects hierarchical groupings of Indian tetraploid wheat genotypes. Theor. Appl. Genet., 99: 868-876.

[30]. Rehman, M., D. Hussain and Y. Zafer.(2002). Estimation of genetic divergence among elite cotton cultivars genotype by DNA fingerprinting technology. Crop Sci., 42: 2137-2144.

[31]. Russell, J.R.; Fuller, J.D.; Macaulay, M.; Hatz, B.; Jahoor, A.; Powell, W. and Waugh, R. (1997).Direct comparison of levels of genetic variation among barley accessions detected by RFLP, AFLPs, SSRs and RAPDs.Theor. Appl. Genet. 95: 714-722.

[32]. Schulmann, A.H. (2007).Molecular markers to assess genetic diversity.Euphytica, 158(3): 313-321.

[33]. Singh, P. and Jaiswal J.P. (2016).Assessing genetic diversity in bread wheat using inter simple sequence repeat (ISSR) markers. Asian Journal ofn bio science.11 (1):141-145.

[34]. Sofalian, O.; Chaparzadeh,N. and Dolati, M.(2008).Genetic diversity in spring wheat landraces from northwest of Iran assessed by ISSR markers.Notul. Bot. Hort. Agric., Cluj-Napoca, 37: 252-256. 
[35]. Solimana, M. I. ; Zaghloul, M. S.; Heikal, Y. M. (2014). Genetic variation within and among three Egyptian esembryanthemum species using different genetic markers, Egyptian journal of basic and applied sciences 1, 127-135.

[36]. Tahir, N. A. (2014).Genetic Variability Evaluation A mong Iraqi Rice (Oryza sativa L) Varieties using RAPD Markers and Protein Profiling. Jordan Journal of Biological Sciences, 7(1): 13 - 18.

[37]. Vishwanath, K.; Prasanna, K. P. R., Pallvi, H. M.; Rajendra P.; Ramegowda, S. and Devaraju, P. J. (2010). Identification of Tomato (Lycopersiconesculentum) Varieties through Total Soluble Seed Proteins Research Journal of Agricultural Sciences, 2(1): 08-12.

[38]. Wettstein-Knowles, P. v (1992).Cloned and mapped genes: Current status. pp. 73-98. In P. R. Shewry, (ed.), Barley: In: Genetics, Biochemistry, Molecular Biology and Biontechnology. Alden Press, Oxford.

[39]. Williams, J. G.; Kubelik, A. R.; Livak, K. J.; Rafaski, J. A. and Tingey, S.V. (1990). DNA polymorphisms amplified by arbitrary primers are useful as genetic markers. Nucleic Acids Res., 18 (22):6531-6535.

[40]. Yousefi, V.; Najaphy, A.; Zebarjadi, A. and Safari, H. (2015).Molecular characterization of Thymus species using ISSR markers. Journal of Animal \& Plant Sciences, 25(4): 1087-1094. 